\title{
I. ARTYKUŁY
}

\author{
DARIUSZ ZAWISTOWSKI
}

\section{NIEZALEŻNOŚĆ SĄDÓW I NIEZAWISŁOŚĆ SĘDZIÓW Z PERSPEKTYWY PRAWA UNII EUROPEJSKIEJ}

\section{WPROWADZENIE}

Przyjmuje się powszechnie, że w państwach demokratycznych niezależność sądów i niezawisłość sędziów należą do filarów państwa prawnego, a rządy prawa są podstawą społeczeństwa demokratycznego, gdyż gwarantują równość obywateli wobec prawa oraz zapewniają ochronę ich praw oraz wolności. Zapewniają także bezstronną kontrolę nad sprawowaniem władzy przez państwo. Koncepcja rządów prawa, która narodziła się w Anglii, oznacza przede wszystkim, że w państwie prawa nikt nie stoi ponad prawem lub poza prawem. Obowiązywanie rządów prawa wymaga, aby podległość prawu była uznawana zarówno przez obywateli, jak i wszystkie organy władzy państwowej, niezależnie od ich charakteru. Dotyczy to zatem władzy ustawodawczej, wykonawczej i sądowniczej. Tego rodzaju podział w wykonywaniu władzy państwowej jest jednocześnie kolejną cechą rządów prawa. W modelu ustroju państwa opartym na zasadzie podziału władz niezależność władzy sądowniczej stanowi kluczowy element rządów prawa.

Doświadczenia historyczne wskazuja, że wszystkie ustroje demokratyczne opierają się na określonym zespole wartości. Sa one, a w szczególności ustrój demokratycznego państwa prawnego, stale zagrożone przez różne czynniki. Obecnie zalicza się do nich terroryzm, fundamentalizm bądź różnego rodzaju radykalizmy oparte często na populizmie, a także komercjalizację i uzależnienie polityczne mediów oraz instrumentalne traktowanie prawa przez rządzących. Ustrój demokratyczny jest chroniony głównie przez obowiązujący system prawa, a władza sądownicza, która stoi na straży rządów prawa, może być z tego względu w pierwszej kolejności poddawana presji ze strony podmiotów nadużywajacych władzy dla realizacji ich celów politycznych. Z tego względu istotne jest pytanie o właściwe rozumienie niezależności władzy sądowniczej. W rozważaniach na ten temat warto uwzględnić podstawowe regulacje prawne zawarte w prawie Unii Europejskiej. Jest to uzasadnione tym bardziej, że koncepcja niezawisłości sądownictwa, przyjmowana początkowo w porządkach krajowych, została z czasem rozszerzona i zasady niezawisłości sędziowskiej zostały ustanowione na poziomie międzynarodowym, a w ostatnim okresie widoczny jest coraz silniejszy wpływ regulacji międzynarodowych na krajowe systemy prawne w tym zakresie. Jako znamienny przykład wskazuje się Zjednoczone Królestwo, w którym orzecznictwo Europejskiego Trybu- 
nału Praw Człowieka wpłynęło na przeniesienie do porządku wewnętrznego europejskiej Konwencji praw człowieka w formie uchwalenia w 1998 r. ustawy o prawach człowieka, a następnie przeprowadzenie w 2005 r. reformy konstytucyjnej, która wprowadziła rozdział między sądownictwem a urzędem lorda kanclerza, stojącego wcześniej na czele sądownictwa i pełniącego jednocześnie ważne funkcje w rządzie i parlamencie.

Wydaje się, że można wskazać na dwie płaszczyzny, w których przepisy prawa unijnego nawiąują do niezależności władzy sądowniczej i podkreślaja jej znaczenie. Pierwsza z nich wynika z zasady państwa prawnego, a druga wiąże się z gwarancją prawa do sądu, jako podstawy ochrony praw i wolności jednostki. Głównie tym kwestiom zostaną poświęcone dalsze rozważania.

\section{NIEZAWISŁOŚĆ SACDOWNICTWA JAKO PODSTAWA PAŃSTWA PRAWA}

Artykuł 2 Traktatu o Unii Europejskiej, określając wartości, na których opiera się Unia Europejska, zalicza do nich obok godności ludzkiej, wolności, równości i demokracji także państwo prawne. Natomiast w preambule do Traktatu znalazło się potwierdzenie przywiąania Unii Europejskiej do zasad wolności, demokracji, poszanowania praw człowieka i podstawowych wolności oraz państwa prawnego. Zasadnicze pytanie dotyczy zatem rozumienia formuły państwa prawnego. Należy przyjać, że pojęcie państwa prawnego, użyte w art. 2 Traktatu o Unii Europejskiej, jest w istocie tożsame z pojęciem demokratycznego państwa prawnego w znaczeniu użytym w art. 2 Konstytucji RP.

Idea państwa prawa powstała już w okresie oświecenia, w opozycji do systemu prawnego państwa absolutnego. Początkowo założenia państwa prawnego obejmowały takie elementy, jak: zasada konstytucjonalizmu, podziału władzy, niezawisłość sądownictwa, uznanie ustawy za podstawowe źródło prawa, podporządkowanie prawu organów władzy państwa oraz demokratyczny tryb tworzenia prawa i jego liberalna treść. Zasady państwa prawnego były z czasem uzupełniane o nowe wartości. Zwracano uwagę na potrzebę rozbudowy w państwie prawnym systemu instytucji i gwarancji przestrzegania prawa przez organy państwowe oraz stworzenia systemu gwarantującego ochronę praw i wolności obywatelskich. Pojawiły się z czasem także elementy państwa prawnego o charakterze socjalnym. Obecnie za podstawy demokratycznego państwa prawnego uznaje się przede wszystkim:

1) zasadę konstytucjonalizmu,

2) suwerenność narodu,

3) podział władzy,

4) uznanie ustawy za podstawowe źródło tworzenia prawa,

5) niezawisłość sądownictwa,

6) istnienie instytucji samorządowych,

7) istnienie konstytucyjnych gwarancji praw i wolności obywatelskich ${ }^{1}$.

\footnotetext{
${ }^{1}$ M. Pietrzak, Demokratyczne, świeckie państwo prawne, Warszawa 1999, s. 33.
} 
Niektórzy autorzy do istotnych cech państwa prawa zaliczają także prawo do rzetelnego i szybkiego procesu sądowego, istnienie mechanizmu kontroli organów sprawujących władzę, zakaz uchwalania ustaw z mocą wsteczną oraz zaangażowanie władz państwowych na rzecz idei sprawiedliwości.

W świetle tych założeń nie powinno ulegać wątpliwości, że niezależność sądów i niezawisłość sędziów są podstawą państwa prawa. Dla niezależności władzy sądowniczej, obejmującej w polskim porządku prawnym sądy i trybunały (art. 173 Konstytucji RP), oprócz wyrażonej wprost zasady niezawisłości sądownictwa - podstawowe znaczenie ma zasada podziału władz. Podział władz oznacza generalnie organizacyjne i funkcjonalne oddzielenie od siebie władzy ustawodawczej, wykonawczej i sądowniczej i ma za zadanie przeciwdziałanie koncentracji władzy, która ułatwia jej nadużywanie. Zasada ta, co oczywiste, nie przewiduje nadrzędności którejkolwiek z tych władz. Uznaje się powszechnie, że bez respektowania zasady podziału władz niemożliwe staje się zagwarantowanie niezależności władzy sądowniczej. Wymaga podkreślenia, że zasada trójpodziału władz zakłada nie tylko wzajemne „hamowanie się władz”, ale także wzajemne poszanowanie kompetencji i współdziałanie między władzami, a zapewnienie niezależności władzy sądowniczej jest wspólnym obowiązkiem wszystkich władz. Do wyłącznej kompetencji władzy sądowniczej należy sprawowanie wymiaru sprawiedliwości, co oznacza, że żaden organ innej z władz nie może ingerować w wykonywanie funkcji orzeczniczych przez sądy. W obrębie władzy sądowniczej do kompetencji Trybunału Konstytucyjnego należy natomiast dokonywanie hierarchicznej kontroli zgodności norm prawnych z normami zawartymi w aktach normatywnych wyższego rzędu, stanowiących wzorzec kontroli. W myśl tej zasady wzorcami kontroli dla ustaw sa normy prawne zawarte w konstytucji lub ratyfikowanych umowach międzynarodowych (art. 188 Konstytucji RP). Wymaga wyraźnego podkreślenia, że zgodnie z art. 190 Konstytucji RP jedynie Trybunał Konstytucyjny jest uprawniony do dokonywania hierarchicznej kontroli zgodności przepisów prawa z wzorcem konstytucyjnym w sposób ostateczny i z moca powszechnie obowiąująca jego orzeczeń. W tym zakresie kompetencje Trybunału Konstytucyjnego nie mogą być przejęte przez żaden inny organ władzy sądowniczej.

W warunkach polskich model demokratycznego państwa prawnego powstał w opozycji do zasady jedności władzy państwowej, obowiązującej w okresie ustroju komunistycznego. Po raz pierwszy stwierdzenie, że Rzeczpospolita Polska jest demokratycznym państwem prawnym pojawiło się w $1989 \mathrm{r}$. w wyniku kolejnej nowelizacji konstytucji z 1952 r. W Polsce instytucje demokratycznego państwa prawnego funkcjonuja zatem stosunkowo krótko. W literaturze podkreśla się, że w państwach postkomunistycznych istnieje niebezpieczeństwo instrumentalnego traktowania prawa. Wyrazem tego jest np. upowszechnianie opinii, że „suweren może prawu nadać taką treść, jaka będzie chciał". Instrumentalne traktowanie prawa uznaje się za wypadkowa tradycji biurokratycznych i autorytarnych praktyk politycznych z poprzednich epok oraz populistycznych interpretacji demokracji zwiąanych z twierdzeniem, że polityczna większość ma zawsze rację. Instrumentalne traktowanie prawa powoduje zaś zwykle „korozję” zasady rządów prawa także wówczas, 
gdy w danym społeczeństwie zdołano wprowadzić jej podstawowe instytucje i procedury ${ }^{2}$.

W Polsce po doświadczeniach ustroju komunistycznego do obowiązującej obecnie Konstytucji wprowadzono szereg gwarancji niezależności władzy sadowniczej. Ustrój państwa został oparty na zasadzie podziału i równowagi władzy ustawodawczej, wykonawczej i sądowniczej (art. 10 Konstytucji RP). Artykuł 173 Konstytucji RP podkreśla dodatkowo odrębność i niezależność władzy sądowniczej od innych władz. Rozwinięciem zasady podziału władz sa przepisy Konstytucji RP przewidujace powoływanie sędziego na czas nieoznaczony (art. 179), nieusuwalność sędziego z urzędu i nieprzenoszalność na inne stanowisko i do innej siedziby (art. 180), uprawnienie do wynagrodzenia odpowiadającego godności urzędu (art. 178) oraz immunitet sędziowski (art. 181). Mogłoby się wydawać, że tego rodzaju gwarancje niezawisłości sędziów i niezależności sądów, przewidziane na poziomie norm konstytucyjnych, są wystarczajace do zapewnienie rzeczywistej niezależności władzy sądowniczej. Wydarzenia ostatnich kilku miesięcy związane z próbami zmian ustawy o Trybunale Konstytucyjnym pokazują jednak, że istnieją w dalszym ciagu zagrożenia w tym zakresie. Udowodniły one także, jak istotna rolę odgrywa w demokratycznym państwie prawnym sąd konstytucyjny, będący gwarantem trwałości rozwiązań ustrojowych zawartych w konstytucji, w tym zasady podziału władz i niezależności władzy sądowniczej. Przykładem znaczącej roli Trybunału Konstytucyjnego w zakresie gwarancji dla niezależności sądownictwa jest wyrok Trybunału Konstytucyjnego z 14 października 2015 r. (Kp 1/15), w którym Trybunał odniósł się do kwestii wykonywania przez Ministra Sprawiedliwości uprawnień w ramach nadzoru administracyjnego nad działalnością sądów powszechnych. Trybunał Konstytucyjny uznał, że przyznanie Ministrowi Sprawiedliwości, w ramach tego nadzoru, kompetencji do żądania akt spraw sądowych w toku trwającego postępowania jest nieuprawnionym wkroczeniem w sferę zastrzeżoną jedynie dla sądów i narusza zasadę niezależności sądów i niezawisłości sędziów. Podkreślił, że zewnętrzny dostęp do akt sprawy, odzwierciedlających przebieg postępowania, może wpływać na sprawowanie wymiaru sprawiedliwości przez zaburzenie toku rozpoznawania sprawy i wywierać presję na sędziego, a tym samym wpływać na sposób rozstrzygnięcia sprawy.

Gwarancję niezależności władzy sądowniczej wprowadza także art. 186 Konstytucji RP, nakładając na Krajową Radę Sądownictwa obowiązek stania na straży niezależności sądów i niezawisłości sędziów. W tym zakresie Rada posiada ważne kompetencje przy obsadzaniu wolnych stanowisk sędziowskich. Jest uprawniona do występowania do Prezydenta o powołanie wskazanych osób na stanowiska sędziowskie. Posiada także uprawnienie do występowania do Trybunału Konstytucyjnego z wnioskami o stwierdzenie niezgodności z Konstytucją aktów prawnych w zakresie, w jakim dotyczą one niezależności sądów i niezawisłości sędziów.

${ }^{2}$ T. J. Stawecki, Niezależność zawodów prawniczych i rzqdy prawa $w$ społeczeństwie postkomunistycznym, w: T. Waradyńki, M. Niziołek (red.), Niezależność sqdownictwa i zawodów prawniczych jako fundamenty państwa prawa, Warszawa 2009, s. 57. 
Rozgraniczenie pojęć niezależności sądów i niezawisłości sędziów wynika z innych płaszczyzn odniesienia. Niezależność sądów jest związana z ich organizacyjnym i funkcjonalnym oddzieleniem od innych organów państwa. Zgodnie ze stanowiskiem Trybunału Konstytucyjnego, wyrażonym w wyroku z 9 listopada 1993 r. (K 11/93), niezawisłość sędziego polega na tym, że sędzia działa wyłącznie w oparciu o prawo, w zgodzie ze swoim sumieniem i wewnętrznym przekonaniem. Niezawisłość sędziowska jest jednak ściśle związana z niezależnością sądów. Pojęcie niezawisłości sędziowskiej obejmuje kilka podstawowych aspektów:

1) bezstronność w stosunku do uczestników postępowania,

2) niezależność wobec organów pozasądowych,

3) samodzielność wobec władz i organów sądowych,

4) niezależność od wpływu czynników politycznych,

5) wewnętrzną niezależność sędziego.

\section{NIEZAWISEOŚĆ SĄDOWNICTWA Z PERSPEKTYWY PRAWA DO SĄDU}

Druga z sygnalizowanych płaszczyzn regulacji zagadnienia niezależności sądownictwa $\mathrm{w}$ prawie unijnym jest związana $\mathrm{z}$ regulacja prawa do sądu. Zgodnie z art. 6 Traktatu o Unii Europejskiej Unia uznaje, że prawa, wolności i zasady określone w Karcie praw podstawowych Unii Europejskiej maja taka samą moc prawna jak Traktaty, a nadto Unia przystępuje do europejskiej Konwencji o ochronie praw człowieka i podstawowych wolności. Natomiast prawa podstawowe, zagwarantowane w europejskiej Konwencji o ochronie praw człowieka i podstawowych wolności, stanowią część prawa Unii jako zasady ogólne prawa. Zgodnie z art. 47 Karty praw podstawowych Unii Europejskiej każdy, kogo prawa i wolności zagwarantowane przez prawo Unii zostały naruszone, ma prawo do skutecznego środka prawnego przed sądem, zgodnie z warunkami przewidzianymi w niniejszym artykule. Każdy ma prawo do sprawiedliwego i jawnego rozpatrzenia jego sprawy w rozsądnym terminie przez niezawisły i bezstronny sąd ustanowiony uprzednio z mocy ustawy. Z kolei art. 6 ust. 1 Konwencji o ochronie praw człowieka i podstawowych wolności stanowi, że każdy ma prawo do sprawiedliwego i publicznego rozpoznania jego sprawy w rozsądnym terminie przez niezawisły sąd. Porównanie tych przepisów z art. 45 ust. 1 Konstytucji RP, stwierdzającym, że każdy ma prawo do sprawiedliwego i jawnego rozpatrzenia sprawy bez nieuzasadnionej zwłoki przez właściwy, niezależny, bezstronny i niezawisły sąd, wskazuje wyraźnie na podobieństwo tych regulacji. Z tego względu zrozumiałe jest wyraźne oddziaływanie art. 6 Konwencji o ochronie praw człowieka i podstawowych wolności oraz art. 47 Karty praw podstawowych, a także orzecznictwa Europejskiego Trybunału Praw Człowieka na właściwe rozumienie prawa do sądu przewidzianego w art. 45 Konstytucji RP. Odpowiednie rozumienie prawa do sądu ma fundamentalne znaczenie dla istnienia i funkcjonowania państwa prawa. 
Powołane wyżej przepisy wskazują na właściwy kontekst, w jakim powinny być oceniane znaczenie i funkcja niezawisłości sędziowskiej w demokratycznym państwie prawnym. W tym modelu ustrojowym zasada niezależności sądów i niezawisłości sędziów służy przede wszystkim realizacji prawa do sądu wyrażonego w art. 45 Konstytucji RP. Przepisy te wskazują też wyraźnie na istniejący związek pomiędzy niezależnością sądów i niezawisłością sędziów a bezstronnością sądu i gwarancją prawa do sprawiedliwego rozpatrzenia sprawy przez sąd. Uzmysławiaja, że niezależność władzy sądowniczej nie jest przywilejem osób sprawujących wymiar sprawiedliwości, jak jest to często przedstawiane społeczeństwu przez niektórych polityków i media, lecz jest to rzeczywista gwarancja ochrony praw i wolności jednostki, szczególnie w jej relacjach z władzą publiczna. Zwrócił na to wyraźnie uwagę Trybunał Konstytucyjny w uzasadnieniu wyroku z 9 listopada 1993 r. (K 11/93). Podkreślił, że pojęcie niezawisłości sędziowskiej, mające swoją ugruntowaną treść, daje podstawową gwarancję bezstronnego podejmowania rozstrzygnięć. Korelatem zasady niezawisłości po stronie sędziego jest obowiąek jego bezstronności. Idzie on czasem dalej niż zakres ochrony zasady niezawisłości. O ile zasada ta odnosi się do oddziaływania podmiotów zewnętrznych, o tyle obowiązek bezstronności obliguje sędziego do przeciwstawiania się ocenom płynącym z jego doświadczenia, stereotypów i uprzedzeń. Niezawisłość sędziowska nie jest wyłącznie podmiotowym uprawnieniem osoby wykonującej zawód sędziego, należy ona bowiem do istoty prawidłowego wykonywania zawodu i w tym znaczeniu niezawisłość sędziego jest również gwarancją praw i wolności obywatelskich.

Orzecznictwo Europejskiego Trybunału Praw Człowieka, w którym często dokonywano wykładni art. 6 Konwencji o ochronie praw człowieka i podstawowych wolności w kontekście właściwego rozumienia pojęcia niezawisłości sędziowskiej, ma niewątpliwie pierwszorzędne znaczenie także dla prawa krajowego. Jest ono często powoływane zarówno przez Trybunał Konstytucyjny, Sąd Najwyższy, jak i sądy powszechne. Europejski Trybunał Praw Człowieka wielokrotnie wskazywał, jakie elementy powinny być brane pod uwagę przy ustalaniu, czy zostały zachowane warunki niezawisłości sądu. Według jego oceny powinno się uwzględnić w szczególności sposób powoływania sędziów, czas trwania ich kadencji, właściwy status materialny sędziów, zasady odpowiedzialności dyscyplinarnej sędziów, procedurę zawieszania lub usunięcia sędziego ze służby i istnienie gwarancji przeciwko presji z zewnątrz, a także kwestię, czy sąd przejawia niezawisłość (zob. np. wyrok Europejskiego Trybunału Praw Człowieka z 25 lutego 1997 r. w sprawie Findlay przeciwko Zjednoczonemu Królestwu). Problem postrzegania sądu jako niezawisłego jest szczególnie istotny z punktu widzenia wymogu jego bezstronności. Odbieranie w społeczeństwie sądu jako niezawisłego i bezstronnego jest uwarunkowane głównie ocena, czy w oczach społeczeństwa posiada on warunki i gwarancje istotne w kontekście swojej niezawisłości. Podkreśla się, że kwestią kluczową dla skuteczności systemu wymiaru sprawiedliwości jest utrzymanie wiary społeczeństwa w niezawisłość i bezstronność sądu. Na wagę tego zagadnienia zwrócił uwagę także Trybunał Konstytucyjny w uza- 
sadnieniu wyroku z 9 grudnia 2015 r. (K 35/15). Odwołał się w nim do wyroku Europejskiego Trybunału Praw Człowieka z 30 listopada 2010 r. w sprawie Henryk Urban i Ryszard Urban przeciwko Polsce. Wymaga zatem podkreślenia, że wzmacnianie zaufania społecznego do wymiaru sprawiedliwości i szerzej - władzy sądowniczej, stanowi ważny czynnik zachowania niezawisłości sędziowskiej. Z tego punktu widzenia próby podważania autorytetu władzy sądowniczej przez przedstawicieli innych władz i nieprzemyślane, doraźne działania podejmowane z przyczyn politycznych godzą nie tylko w zasady demokratycznego państwa prawnego, ale także w gwarancje dotyczace ochrony praw i wolności obywatelskich.

Należy mieć także na uwadze, że niezależność sądów i niezawisłość sędziów sa ściśle powiązane z zasadami odpowiedzialności władzy sądowniczej. W systemie obowiązującego prawa istnieje szereg mechanizmów kontroli właściwego działania władzy sądowniczej, w tym możliwość naprawienia szkody spowodowanej wydaniem niezgodnego z prawem orzeczenia. Sami sędziowie ponoszą odpowiedzialność przed społeczeństwem zarówno za działania związane z wykonywaniem czynności urzędowych, jak i za zachowanie poza służbą. Przyznanie sędziom atrybutów niezawisłości wiąże się z postawieniem im wysokich wymagań w zakresie kompetencji zawodowych i sposobu zachowania, także w życiu prywatnym. Muszą być one zgodne z zasadami etyki sędziowskiej i nakładają na sędziów daleko idące ograniczenia osobiste, znacznie poważniejsze niż w przypadku zwykłych obywateli. Jest to konieczne do zapewnienia zaufania społecznego do systemu wymiaru sprawiedliwości.

\author{
Dariusz Zawistowski \\ Przewodniczacy Krajowej Rady Sqdownictwa \\ oraz Sędzia Sądu Najwyższego
}

\title{
INDEPENDENCE OF THE COURTS AND JUDICIAL INDEPENDENCE FROM THE EUROPEAN UNION LAW PERSPECTIVE
}

Sum mary

\begin{abstract}
The independence of the courts and the judiciary constitutes one of the foundations of the rule of law and is one of the basic values of the European Union. Judicial independence is also guaranteed by the principle of the separation of powers. According to this principle courts are the only competent body to execute judiciary powers and no other organs may be permitted to interfere in judicial decisions or their making. Democratic states must have the independence of the courts ensured in their constitutions. The basic function of judicial independence is ensuring citizens the right to a fair trial as provided in Article 6 of the Convention for the Protection of Human Rights and Fundamental Freedoms and Article 45 of the Constitution of the Republic of Poland. From the point of view of the right to a fair trial the relationship between the independence of the courts and judicial independence on the one hand and the guarantee of the impartiality of the courts and of a fair trial on the other, is important. The independence of the courts and the judiciary is closely related to the principle of the responsibility of judicial authority.
\end{abstract}


